\title{
A NEW SPECIFIC NAME IN COLLETES (COLLETIDAE, APOIDEA)
}

\author{
Jesus Santiago Moure ${ }^{1}$
}

\section{Colletes atacamanus nom.n.}

The species Colletes atacamensis was published by MOURE [1956 Dusenia 7 (4): 204.5] for a new species of Colletes from San Pedro, Atacama, Chile. One year before the same name was published by JANVIER [1955 Ann. Sci. Nat. Zool. 17 (11): 311 and 316-317] for a different species from Quillaga, Chile.

This homonymy was communicated to me by Dr. Michael Kuhlmann who is preparing a revision of the old world species of the bee genus Colletes. I'm very grateful to Dr. M. Kuhlmann for calling my attention to this junior homonymy. To solve this nomenclaturial problem I propose Colletes atacamanus as a new name for my species Colletes atacamensis Moure, 1956 non atacamensis Janvier, 1955.

1) Contribuição número 1023 do Departamento de Zoologia , Universidade Federal do Paraná.

2) Departamento de Zoologia, Universidade Federal do Paraná. Caixa Postal 19020, 81531-990 Curitiba, Paraná, Brasil. 